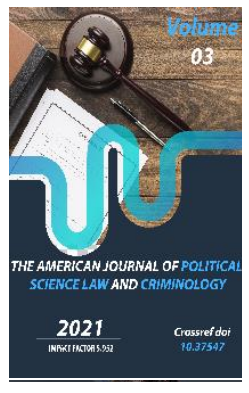

Copyright: Original content from this work may be used under the terms of the creative commons attributes 4.0 licence.

\section{Uzbek Laws Provide Responsibility For Violation Of Democratic Election Principles}

\author{
B.D. Akhrarov \\ Deputy Head Of The Department For Combating Economic Crimes Under The General \\ Prosecutor's Office Of The Republic Of Uzbekistan
}

\section{Sh.X. Alirizaev}

Deputy Head Of The Department For Combating Economic Crimes Under The General Prosecutor's Office Of The Republic Of Uzbekistan

\title{
ABSTRACT
}

Building a democratic state governed by the rule of law and a free civil society is unimaginable without elections. After all, in the election process, the diversity of opinions in society, the will, aspirations, social moods of the people are clearly reflected. Democratic elections, which reflect the diversity of views in society, the aspirations and aspirations of the people, must be legally protected. Liability for violation of the principles of democratic elections has been established.

\section{KEYWORDS}

Electoral law, human rights, society, political rights, responsibility, citizens, civil rights, international pact, administrative, criminal, political party, official.

\section{INTRODUCTION}

As a result of the elections held under the motto "New Uzbekistan - New Elections" in the Address of the President of the Republic of Uzbekistan Sh.M.Mirziyoev for 2020, a new political environment has emerged, which is necessary to bring democratic reforms to a higher level. Article 18 of the State Program of the Republic of Uzbekistan for 2021 sets out 
specific measures for the preparation and conduct of elections of the President of the Republic of Uzbekistan at a high level. According to the program, preparations for the March 1 presidential election on democratic principles have begun. It should be noted that during the years of independence, Uzbekistan has created a modern electoral system that meets democratic requirements as a result of reforms in all spheres of social life. In accordance with the universally recognized international principles of elections, legislation has been developed that guarantees the free expression of the will of citizens, the right of everyone to freely elect and be elected to representative bodies of state power. Legal mechanisms to ensure openness and transparency in the election process have been improved. As noted by President Mirziyoyev, "According to our Constitution, citizens have the right to participate in the management of state and public affairs directly and through their representatives. Voting for and supporting a program put forward by a candidate or any party in the election is a clear manifestation of representative democracy" [1].

The adoption of the law on amendments and additions to some articles of the Constitution of the Republic of Uzbekistan is a logical continuation of the ongoing process of democratic renewal in our country. In particular, the Law of September 4, 2019 "On amendments and additions to some legislative acts of the Republic of Uzbekistan in connection with the improvement of electoral legislation" replaced the fourth part of Article 117 of the Constitution with the fourth and fifth paragraphs as follows: citizens, as well as persons detained in places of deprivation of liberty by court order, may not be elected.
Persons who have been declared incompetent by a court, as well as those detained in places of deprivation of liberty for the commission of serious and very serious crimes, shall not participate in elections. In any other case, direct or indirect restriction of citizens' suffrage shall not be allowed." This norm restores the right to vote to our citizens who are serving sentences for less serious and less serious crimes.

The Electoral Code of the Republic of Uzbekistan, adopted on 28 February 2019 and entered into force on 26 June, stipulates that citizens of the Republic of Uzbekistan are equal regardless of gender, race and nationality, language, religion, social origin, beliefs, personal and social status, education, type and nature of training. has the right to vote (Article 4).

As a result of the reform of suffrage in the Republic of Uzbekistan, the current electoral legal framework has reached a level that meets international electoral standards and meets all the important modern principles and norms of organizing and conducting democratic elections, taking into account national characteristics.

At the same time, in all democratic electoral processes, even in the elections themselves, there are various violations that illegally restrict the voting rights of citizens.

A number of provisions of the newly adopted Electoral Code set out general norms for liability for violations of election legislation. In particular, Article 11 (System of Election Commissions), Part 3 of the Electoral Code states that "interference in the activities of election commissions is not allowed and such 
interference is punishable by law. Article 38 (Procedure for collecting signatures) Part 5 Collection of voters' signatures, at the place of residence, at election events, as well as in other places where campaigning and collecting signatures are not prohibited by law. It has been established that any form of coercion and embezzlement of voters by a person collecting signatures is subject to statutory liability. Article 103 of this Code introduces a norm of liability for violation of the electoral legislation.

International law also guarantees the right to vote and protection from unlawful obstruction of its exercise. For example, Article 21, Section 3, of the Universal Declaration of Human Rights states: "The will of the people shall be the basis of government; this will must be expressed in periodic and non-fraudulent elections, on the basis of universality and equality, by secret ballot or by other means of ensuring freedom of voting "[2].

Article 25 of the International Covenant on Civil and Political Rights states: have the right and opportunity to vote and stand for election in real elections. "[3]

This issue is covered in more detail in the document of the Council held in Copenhagen within the framework of the Conference on Human Criteria of the Organization for Security and Cooperation in Europe.

The mechanisms of administrative or criminal protection of the suffrage of the citizens of any state have general features, as well as aspects that are unique to that state.

In particular, the Code of Administrative Responsibility of the Republic of Uzbekistan was supplemented with a new chapter consisting of eight articles - Chapter V1
"Administrative liability for violations in the organization and conduct of elections and referenda".

The strict definition of liability for violations of the electoral law will serve to strengthen the implementation of the principle of electoral freedom, further democratization of the electoral system of the country, strengthening the principles of openness and transparency of elections.

According to the Code of Administrative Responsibility, actions such as violation of the rights of a candidate for the President of the Republic of Uzbekistan, a proxy, an observer, the terms and procedure of the election campaign are subject to administrative liability.

Also, actions aimed at deliberately publishing false information about a candidate or a political party in order to influence the election results will also lead to the imposition of administrative sanctions.

In accordance with the Election Law, election commissions are independent of public authorities, public associations, political parties and officials within their competence. In order to organize the election process in a legal, fair and equal manner for all participants in the elections, it is very important that the members of the election commission act independently. Failure to do so in practice undermines the democratic nature of elections.

Failure to comply with the decisions of election commissions within their competence shall entail administrative liability against officials.

The Criminal Code of the Republic also contains norms providing for criminal liability for violation of electoral legislation. 
Article 146 of the Criminal Code of the Republic of Uzbekistan provides for liability for violation of the legislation on the organization or conduct of elections or referenda, and Article 147 provides for liability for obstruction of the right to vote or the powers of proxies.

Acts related to the organization of elections or referendums, which lead to criminal liability, and violations of the legislation on their conduct are defined in Article 146 of the Criminal Code. These include: violations committed by officials, representatives of political parties or citizens' self-government bodies, members of election commissions or referendum commissions during elections or referenda, in particular, violation of the secrecy of the ballot, falsification of election documents or referendum documents, ballot papers and making false entries on signature sheets, deliberate miscalculation of votes.

In the case of this crime, the constitutional right of citizens to vote, the procedure for organizing and conducting referendums and elections are violated.

The right to vote is the right of a citizen to participate in elections guaranteed by the state, which means the right to vote (active suffrage) and to be elected (passive suffrage).

A referendum is an expression of the will of the people by voting on the most important issues in the life of the state and society.

Elections are a political and legal process dedicated to the election of citizens by the President of the Republic of Uzbekistan, deputies of the Oliy Majlis, deputies of regional, district and city Kengashes.
In the Republic of Uzbekistan, voters have the right to freely express their wishes and will and to vote by secret ballot. By allocating special rooms for voting in precinct election commissions, citizens will be able to freely express their wishes and will. Secret ballot implies that the voter has no control over the expression of his or her will.

Violation of the secrecy of the ballot means an act (omission) committed for a situation that arose with the intention of knowing the wishes and will of the participant of the election (referendum). This leaves polling stations without special booths guaranteeing secret ballots; not to allow a voter into such a booth; enter the booth and observe the voting process; illegal review of completed ballots; may be reflected in the numbering of ballots and so on.

Falsification of election documents or referendum documents is reflected in the introduction of false, ie inaccurate, information into the original (official) documents. However, all the features and details that indicate that the document is authentic are retained. Counterfeiting of documents, or more precisely, the creation of forged documents in form and content, or the making of a partial error in the original document, is also considered forgery. In both cases, it should be noted that the falsification violates the will of the person participating in the election or referendum.

False entries in ballot papers or ballot papers are, in essence, a form of falsification of election documents or referendum documents, which is reflected in the inclusion of inaccurate entries (information) in the 
original document, while retaining the original features and details of the document.

Deliberate miscalculation of votes is a deliberate falsification of the election results, ie an increase or decrease in the number of "for" and "against" votes cast for a candidate, or a deliberate falsification of the referendum results.

Criminal liability under Article 146 of the Criminal Code of the Republic of Uzbekistan arises from the moment of organization of an election or referendum, one of the actions aimed at violating the legislation on their conduct, regardless of whether there is a social threat.

The crime may have been committed by an official over 18 years of age, representatives of a political party or citizens' self-government body, members of election commissions or referendum commissions.

An official is a person who performs the functions of a government representative on a permanent, temporary or special basis, or who performs organizational, managerial, administrative and economic functions in state bodies, self-government bodies, government agencies.

Article 32 of the Constitution of the Republic of Uzbekistan states that citizens of the Republic of Uzbekistan have the right to participate in the management of public and state affairs directly and through their representatives. Such participation is achieved through selfgovernment, referendums and the democratic organization of state bodies. Violation of this political right is punishable under Article 147 of the Criminal Code of the Republic of Uzbekistan.
Obstruction of the exercise of the right to vote or the powers of proxies (Article 147 of the CC) manifests itself in the use of force, intimidation, deception or obstruction.

In the commission of a crime under Article 147 of the Criminal Code of the Republic of Uzbekistan, the right of a citizen to vote or to be elected, to conduct election campaigning, to participate in a referendum is violated. That is, their active and passive suffrage is violated.

Active suffrage is a constitutional right of citizens of the Republic of Uzbekistan to be elected to public authorities and selfgovernment bodies. Passive suffrage is a constitutional right of citizens of the Republic of Uzbekistan to be elected to public authorities and self-government bodies.

The right to conduct election campaigning is a constitutional right of citizens of the Republic of Uzbekistan to participate in referendums, as well as to vote on draft laws and regulations, current laws and regulations, and other important state issues.

Obstruction is the use of violence, intimidation, lying, or bribery to a voter or candidate's representative in order to prevent the exercise of a voter's right to vote or to participate in a referendum (for example, to prohibit campaigning, not to be included in the voter list, etc.). method.

In this case, violence means any physical influence that prevents a citizen from exercising his right to vote or exercising the powers of the persons he represents. Such violence may be manifested in the form of minor or moderate injuries, beatings, unlawful deprivation of liberty, and so on. 
Unlawful deprivation of liberty is the detention of a person in a certain place who came voluntarily but does not want to stay there anymore, or to keep him in a certain place despite the person's resistance.

Obstruction of a citizen's right to vote or exercise of the powers of the persons represented is committed in connection with the unlawful deprivation of liberty by force, the act is qualified as a total offense under Articles 138 and 147 of the CC.

Intimidation is when a victim exercises his / her right to vote or acts as a trustee, in various ways (written, verbal) to harm his / her personal interests (life, health, property, honor, pride, etc.) or relatives and friends protected by law. , gestures, etc.) is the described psychological pressure.

Deception is the intentional misrepresentation of a person's right to participate in elections, referenda, and campaigning, as well as the date, process, time, address, order of ballots, and similar information necessary for a citizen to freely participate in election campaigns and elections. improper transmission is implied.

Extortion means money or various privileges or incentives provided to a person or a member of an election commission for obstructing the work of an election commission in exchange for not participating in election campaigns, elections, referendums.

The guilty person shall be held liable in accordance with Article 147 of the CC from the moment of the commission of one of the above acts, regardless of whether the voter or the candidate's representative could in practice impede the exercise of the relevant constitutional rights and powers.
Any sane person who has reached the age of 16 who has obstructed the exercise of the right to vote or the powers of a trustee shall be the subject of a crime.

The commission of this crime by an official and the existence of other necessary aspects shall give rise to liability under Articles 147 and 205 or 206 of the CC.

In conclusion, it should be noted that the universally recognized norms of international law and the national electoral system of the Republic of Uzbekistan, created in accordance with the Constitution, allow us to conclude that an effective legal mechanism has been created to protect the democratic principles and norms of electoral rights.

During the years of independence, as a result of consistent, gradual modernization and renewal of political, state and legal systems in Uzbekistan, an electoral system that meets high democratic requirements has been formed. Creation of an effective, democratic electoral system - the formation of a completely new system of state power, democratic renewal of socio-political construction, ensuring the principles of separation of powers, deep socio-economic reforms that are reflected in the rapid development of the real economy, living standards and welfare has become an important part of the work being done to increase.

Indeed, the system of national electoral legislation created on the basis of the Constitution of the Republic of Uzbekistan fully meets the universally recognized democratic requirements and international standards. Most importantly, the national election laws 
adopted in our country create an effective mechanism for citizens to exercise their political, social and economic rights through the exercise of suffrage. It should be noted that the growing legal culture of the electorate today contributes to the free and fair conduct of elections in many respects within the law. All of these factors serve to ensure that voters pass the election process at a high level by voting responsibly in choosing the most suitable alternative candidate. It is obvious that the provisions enshrined in the electoral legislation of the Republic of Uzbekistan provide adequate rights and guarantees for citizens to participate in the management of state and public affairs through participation in elections and referendums, in particular through direct participation in addressing important issues of the country's future.

The establishment of legal liability, ie administrative or criminal liability, for violations of electoral law in the organization or conduct of elections, infringement on the freedom of citizens to participate in elections, serves as a guarantee of protection of citizens' suffrage and suffrage from any violations.

\section{REFERENCES}

1. Speech by President Sh. Mirziyoyev at the solemn ceremony dedicated to the 27th anniversary of the adoption of the Constitution of the Republic of Uzbekistan entitled "The Constitution and the rule of law are the most important criteria of a democratic state and civil society." $2019 \mathrm{y}$. December 7 .
2. Universal Declaration of Human Rights. Adopted by General Assembly Resolution 217 A (III) of 10 December 1948.

3. The International Covenant on Civil and Political Rights was adopted by Resolution 2200 (XXI) of the General Assembly on 16 December 1966 and declared open for signature, ratification and accession. Entered into force on 23 March 1976.

4. Law "On amendments and additions to some legislative acts of the Republic of Uzbekistan in connection with the improvement of the electoral legislation", September 4, 2019.

5. Electoral Code of the Republic of Uzbekistan (National Database of Legislation, 26.06.2019, No. 03/19/544/3337; No. 09/02/2021, No. 03/21/670/0089).

6. Code of the Republic of Uzbekistan on Administrative Responsibility. Tashkent "Uzbekistan" 2020.

7. Criminal Code of the Republic of Uzbekistan. Tashkent "Uzbekistan" 2020.

8. The Constitution of the Republic of Uzbekistan. Tashkent "Uzbekistan" 2020. 